Knut Steinar Engelsen,

Førsteamanuensis ved Avdeling for lcererutdanning og kulturfag, Høgskolen Stord/Haugesund

\title{
Trond Eiliv Hauge, Andreas Lund og Jon Magne Vestøl: Undervisning i endring - IKT, aktivitet, design Bokanmeldelse
}

Denne bokas hovedambisjon er å bidra til utvikling av ny innsikt i forhold til hvordan undervisning og læringsaktivitet skal forstås og utøves i en tid da betingelsen for læring er i rask endring. Forfatternes uttalte hensikt er slik å knytte en forbindelse mellom sosiokulturelle læringsperspektiver og klasseromspraksiser.

Bokas første del tar opp temaet "Undervisning som utfordring”. Ved hjelp av eksempler fra skolen tegnes det her raskt opp et bilde av den kompleksitet som i dag preger formelle og uformelle læringssituasjoner. Dette er noe som ikke minst er forårsaket av det press som ny informasjonsteknologi har satt på vår forståelse av begreper som læring og undervisning. Med utgangspunkt i en sosiokulturell tilnærming presenterer forfatterne noen begreper og perspektiver og lanserer disse som redskap for å forstå de utfordringene som denne kompleksiteten reiser. Sentrale begreper som trekkes inn i diskusjonen, er for eksempel nettverk og dialog. I lys av forfatternes sosiokulturelle tilnærming lanseres videre en dynamisk kunnskapsforståelse som alternativ til forståelsen av kunnskap som noe dekontekstualisert og statisk "sant". Sentralt i en slik kunnskapsforståelse står, som det også blir fremhevet i bokas epilog, en erkjennelse av noen sentrale spenningsfelter som oppstår i læringsaktiviteter. Det dreier seg om spenninger som oppstår mellom bestående (og gitt) kunnskap på den ene siden og ny kunnskap som utvikles gjennom læringsaktiviteten på den andre. Videre kan det være knyttet til forholdet mellom individuell læring og kollektiv kunnskapsutvikling.

I bokas andre del, "Undervisning som samhandling”, utvikles og konkretiseres det teoretiske rammeverket. Siktemålet her er å vise hvordan man kan forstå og håndtere de pedagogiske utfordringene som de nye betingelsene for læring reiser. Her presenteres aktivitetsteoriens analytiske begrepsapparat som redskap for å forstå komplekse læringsaktiviteter. Sentralt i en slik tilnærming står erkjennelsen av at læringsaktivitetens hensikt og retning (objekt) utvikles gjennom det kollektive samspillet mellom de involverte aktørene (for eksempel elever og lærere) og bruken av kulturelle redskaper (som for eksempel IKT).

I tredje del, "Undervisning som sosial og kulturell praksis”, brukes konkrete eksempler fra skolen for å utdype og konkretisere ulike aspekter ved sosiokulturell læringsforståelse. Her gås det blant annet i dybden på det nye 
literacy-begrepet som er under utvikling, og det synliggjøres hvorfor de nye betingelsene for læring også krever at nye briller brukes for å forstå hva kunnskap er, og hvordan læring foregår. Noen grunnleggende forutsetninger for en slik forståelse er en overskridelse av individperspektivet, av tradisjonelle grenser for hvor og når læring foregår, og av grenser for hvem som har kontroll på læringsaktiviteten.

I bokas siste del, ”Undervisning som design”, fokuseres det på hvordan læringsaktiviteter kan organiseres i lys av en sosiokulturell tilnærming. Ved hjelp av eksempler fra lærerutdanningen vises det hvordan man kan designe støttestrukturer for læringsaktiviteten. Samtidig synliggjøres hvordan selve objektutviklingen kan inngå som produktivt element i design- og læringsprosesser.

De siste årene har det kommet mye produktiv litteratur om hvordan for eksempel kompetansebegrepet skal forstås i lys av de nye informasjons- og redskapstrukturer som har oppstått i kjølvannet av internett-revolusjonen. Samtidig er mange spennende didaktiske utviklingsprosjekter på ulike nivåer blitt gjennomført og dokumentert. Med den ambisiøse hensikt å fylle et tomrom mellom læringsteori (det å forstå) og metodiske veiledninger (det å utøve) gir denne boka slik sett en ny dimensjon til denne floraen av pedagogisk litteratur. Forfatterne lykkes godt med å vise hvordan ulike sider ved samfunnsutviklingen, ikke minst innføring av ny informasjonsteknologi, nødvendigvis må føre til at våre tradisjonelle oppfatninger om læring og undervisning settes under press. Samtidig er boka klar på at lærerens rolle i den nye tida, om mulig, er enda viktigere enn før. Dette er et spesielt viktig poeng i en tid da mange, også lærere, har misforstått den nye situasjonen dit hen at nå skal læringsaktiviteten individualiseres og ansvaret plasseres alene hos den lærende. Budskapet i denne boka er det motsatte, blant annet ved at de kollektive aspektene ved læring fremheves så sterkt. Som grunnfjell i den læringsforståelse som boka er tuftet på, står erkjennelsen av at læring er noe som foregår i et samspill mellom de lærende (som oftest elevene) og de mer kompetente andre (som oftest læreren).

Primær målgruppe for boka oppgis å være lærerstudenter med framtidig karriere i ungdomsskole og videregående skole, samt lærere i lærerutdanningen. Videre vises det til at lærere og læringsforskere vil finne mye interessant i boka. Dette er en svært differensiert målgruppe, og spørsmålet blir da om boka klarer å fylle tomrommet mellom læringsteori og metodiske veiledninger for alle disse gruppene. Forfatterne klarer på en opplysende måte å forklare hvorfor det $\mathrm{i}$ vår tid er nødvendig å utvide kompetansebegrepet. Jeg er videre enig med forfatteren av bokas epilog, Sten Ludvigsen, i at boka makter å vise oss hvordan det sosiokulturelle perspektivet kan hjelpe oss til å forstå hvordan læring kan planlegges. Langt på vei mener jeg at dette er aspekter som kommuniseres godt ut til de ulike lesergrupper. Når det gjelder de mer analytiske perspektivene som reises, er jeg nok likevel av den oppfatning at dette er mer en bok for akademikere med god teoretisk skolering enn for studenter og lærere i skolen. 
De aktivitetsteoretiske prinsippene er kompliserte, og knytningen mellom disse og de praktiske eksemplene kunne muligens vært gjort enda tydeligere, ikke minst om ambisjonen er å stimulere til diskusjon blant lærerne i skolen. På den andre siden kan man også stille spørsmål ved om aktivitetsteorien egner seg til nettopp en slik forenklet fremstilling, eller om dette er en teoretisk tilnærming som er og bør være dedikert til den forskningsmessige diskursen?

Jeg vil likevel til slutt understreke at Hauge, Lund og Vestøl alt i alt har skrevet og redigert en viktig og velskrevet bok som vil fungere som en komplementær stemme i forhold til de mer instrumentalistiske og tellekantprega måtene å angripe skoleproblemer i Norge på, i kjølvannet av bl.a. PISA. Det er å håpe at bokas budskap også kan bringes ut til lærerne og brukes som et refleksjonsgrunnlag i en tid hvor mange lærere føler et sterkt teknologipress fra skolemyndigheter, foreldre og elever. Trolig vil boka her "trives best" som hjelpeverktøy i en aktiv dialog mellom forskningsmiljøene og praksisfeltet.

Trond Eiliv Hauge, Andreas Lund og Jon Magne Vestøl:

\section{Undervisning i endring - IKT, aktivitet, design}

Abstrakt Forlag, 2008

232 sider 